\title{
Derivatives Use
}

\section{The relation between bid-ask spreads and price volatility in forward markets}

\author{
Roy A. Batchelor, Amir H. Alizadeh* and Ilias D. Visvikis \\ ${ }^{*}$ Faculty of Finance, City University Cass Business School, 106 Bunhill Row, London \\ EC1Y 8TZ, UK. Tel: +44 2070400 199; E-mail: a.alizadeh@city.ac.uk
}

Received (in revised form): 5th October, 2004

\begin{abstract}
Roy A. Batchelor is HSBC Professor of Banking and Finance at City University Cass Business School in London, and Visiting Professor of Finance at ESCP-EAP, Paris. He has acted as consultant to a leading firm of London stockbrokers, an international market research organisation, the London International Financial Futures Exchange (LIFFE), the World Gold Council and a number of governmental committees.
\end{abstract}

Amir H. Alizadeh is a senior lecturer and Director of the MSc Energy, Trade and Finance at City University Cass Business School, London. He has published in several academic journals in the areas of transportation, finance and economics.

Ilias D. Visvikis is an assistant professor of finance and Academic Director of the MBA in Shipping Program at ALBA Graduate Business School, Athens, Greece. He has published in several academic journals and market-oriented periodicals in the areas of finance, risk management and shipping.

\section{Practical applications}

Forward freight agreement (FFA) contracts have become the main risk management instrument in the sea transportation industry. In recent years, there has been a huge increase in the numbers of shipping companies, commodity trading houses and financial institutions trading FFAs. This study examines the relationship between bid-ask spread and expected volatility in the freight market. The results of this study provide a better understanding of the movements of FFA prices and their consequent effect on transactions costs. Market agents using information on the behaviour of bid-ask spreads can have a better insight about the timing of their FFA transactions and the future direction of the FFA market, as a widening bid-ask spread corresponds to an anticipation of increased future volatility.

\begin{abstract}
The forward freight agreement (FFA) market developed in the 1990s and is growing very fast
\end{abstract}

Derivatives Use, Trading \& Regulation, Vol. 11 No. 2, 2005, pp. 105-125 Publications, Publications,
$1747-4426$ bid-ask spreads (BASs) in this derivatives market where the underlying asset is a service rather than physical or financial assets. The study employs a two-step modelling specification. In the first step, the GARCH specification is used to model the volatility of the FFA prices; in the second step, the relationship between 
expected conditional volatility (led by one day)

and the current BAS using the generalised

method of moments (GMM) approach is

investigated. The results indicate that there is a

positive relationship between $B A S$ s, and expected

price volatility in three out of four FFA

contracts, after other factors are controlled.

\section{INTRODUCTION}

The forward freight agreement (FFA) market was developed in the 1990s and is growing very fast as the main derivatives market offering agents in the shipping and transportation industry a risk management instrument. FFAs agreements are derivatives contracts traded in an over-the-counter (OTC) market where two parties must agree to do business with each other while accepting credit risk from the other party. ${ }^{1}$ The primary advantage of an OTC market is that the terms and conditions are tailored to the specific needs of the two parties. Since this market is a private market in which the general public does not know that the transaction was done, it does not normally require initial, maintenance and variation margins, which are common in the futures organised exchanges. ${ }^{2}$

The aim of the formalisation of the FFA market during the 1990s was to provide a mechanism for hedging freight rate risk in the dry-bulk and wet-bulk sectors of the shipping industry. FFAs agreements are principal-to-principal contracts between a seller and a buyer to settle a freight or hire rate for a specified quantity of cargo or type of vessel for usually one, or a combination of, the major trade routes. Currently, FFA contracts have as the underlying asset spot freight rates in routes of the Baltic Panamax Index (BPI), the Baltic Handymax Index (BHMI), the Baltic Capesize Index (BCI) and the Baltic International Tanker Routes Index (BITR). One counterparty takes the view that the price of an agreed freight route, at an agreed time, will be higher in the future. $\mathrm{He} /$ she buys FFA contracts (charterer) in order to sell them in the future at the higher price and thus controls for the possibility of paying higher spot rates in the future. The other party takes the opposite position and sells FFA contracts (shipowner). Settlement is made on the difference between the contracted price (forward price) and the average price for the route selected in the index over the last seven working days.

The growth of transactions in the FFA market is also evidenced in Figure 1, which presents the estimated notional amount of freight contracts traded in the FFA market. The graph also illustrates the decline in annual volume of previously traded freight futures contracts in the London International Financial Futures Exchange (LIFFE) known as the 'Baltic International Freight Future Exchange' (BIFFEX). It can be seen that the trading volume of BIFFEX contracts has been dropping steadily, particularly since 1995, when trading in FFA contracts really started to grow owing to the ineffectiveness of BIFFEX contracts in risk management.

In the OTC FFA market, there are no official organised exchanges, but there is a network of shipbrokers who act as FFA brokers; transactions occur only when buy and sell ask orders are matched. The 
Figure 1: Volume of transactions in the FFA and BIFFEX markets. Reported figures are market estimates. It is estimated that, on average, one FFA contract has the same monetary value as approximately 75 BIFFEX contracts.

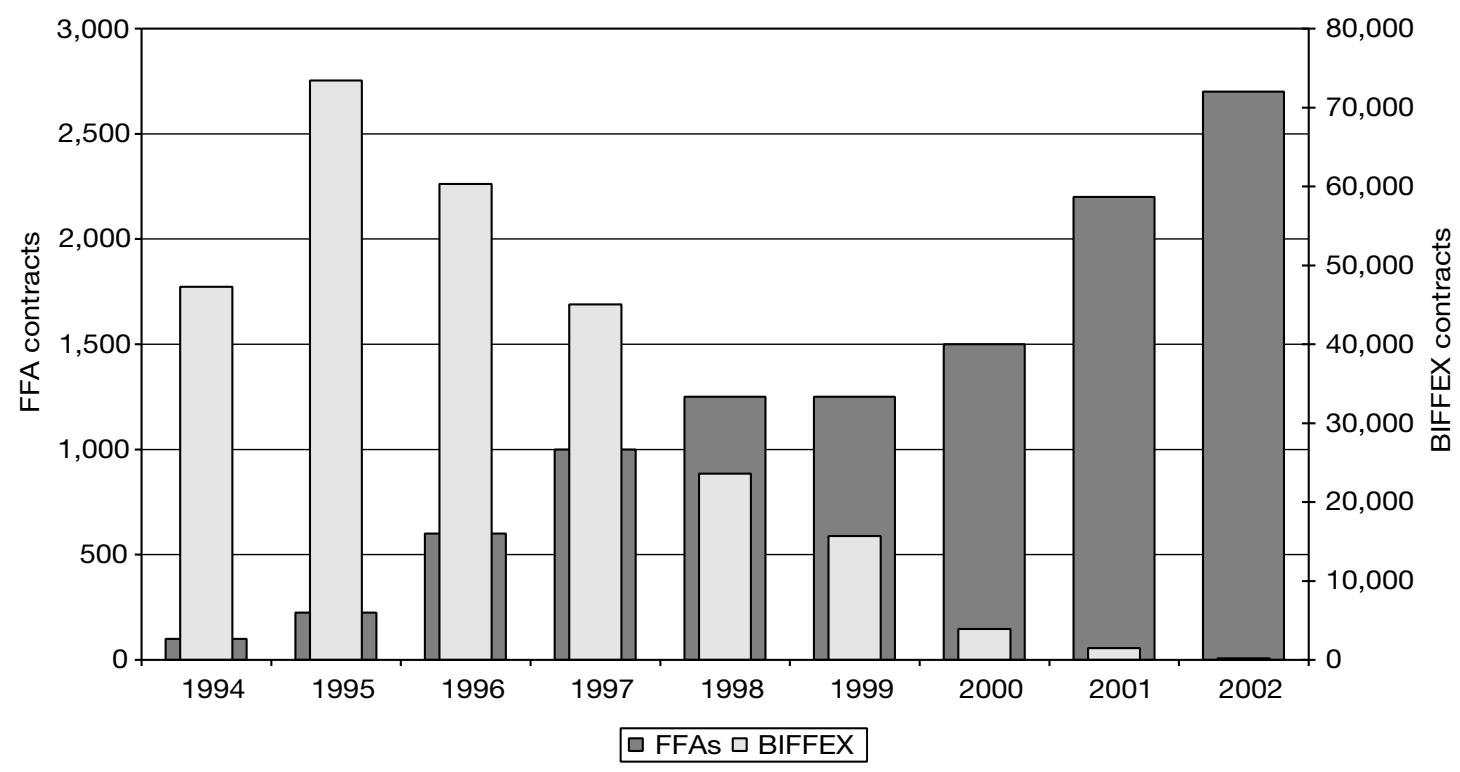

FFA, Forward Freight Agreement; BIFFEX, Baltic International Freight Future Exchange. Source: Simpson, Spence and Young (SSY) Futures.

shipbrokers supply the market by quoting daily bid and ask prices simultaneously against which market orders can be executed. In the trading process, interest in buying or selling forward contracts is relayed by telephone or a computerised order-entry system by the shipbrokers to all potential traders. On receiving the replies, the shipbrokers try to match the bid and ask prices by continuously negotiating with the two parties. If an agreement is reached, the contract is fixed. During this process, the daily bid and ask prices are directly observable and, therefore, there is no need to estimate them as in other derivatives markets. Several procedures have been proposed for the estimation of the BAS (and its components) when it is not directly observable (see, for example, Bhattacharya, ${ }^{3}$ Roll, ${ }^{4}$ Choi et al., ${ }^{5}$ Thompson and Waller, ${ }^{6}$ George et al., ${ }^{7}$ Laux and Senchack ${ }^{8}$ and Chu et al. $\left.{ }^{9}\right)$. For a formal discussion of the alternative BAS estimators see Ding. ${ }^{10}$

Transaction costs are usually ignored in asset pricing theories but they are an important consideration in investors' investment decisions. One significant cost is the BAS. Brokers match buy and sell contracts, and the price charged for this service is known as the BAS - the difference between the buying (bid) and selling (asked) price per contract. This is 
normally regarded as compensation to brokers for providing liquidity services in a continuously traded market. The mark-up charged by brokers in the financial markets, as in any other market, is a function of the operational efficiency of the brokers and the nature of the product. Tinic and West ${ }^{11}$ argue that there is a positive relationship between spreads and price volatility on the grounds that the greater the variability in price, the greater the risk associated with the performance of the function of the brokers. Intuitively, unambiguous good or bad news regarding the fundamentals of the price of the asset should have no systematic effect on the spread. Both the bid and the ask prices should adjust in the same direction in response to the traders receiving buy or sell orders that reflect the particular news event. Greater uncertainty regarding the future price of the asset, however - as associated with greater volatility of the price of the asset - is likely to result in a widening of the spread (see Bollerslev and Melvin ${ }^{12}$ ).

The nature and the behaviour of the BASs have been examined thoroughly in the financial markets (see McInish and Wood $^{13}$ for equity; Bessembinder ${ }^{14}$ and Bollerslev and Melvin ${ }^{12}$ for foreign exchange; and Kalimipalli and Warga ${ }^{15}$ for bond markets). The relationship between BAS and volatility in derivatives markets has also been examined in a number of studies (for example, Laux and Senchack, ${ }^{8}$ Ma et al., ${ }^{16}$ Wang et al., ${ }^{17}$ Ding $^{10}$ and Wang and $\mathrm{Yau},{ }^{18}$ among others). BAS, which is a component of the transaction costs related to derivatives trading, is an important issue because the low cost of trading is often cited as one rationale for the existence of derivatives markets. High transaction costs will normally affect market participants' abilities to trade quickly and cheaply. Therefore regulators (Forward Freight Agreement Brokers Association - FFABA) will need to consider how their policy decisions may affect the volatility of the market and, consequently, the BASs.

There have been a number of studies on the behaviour of the FFA prices levels and volatilities, ${ }^{19-21}$ yet there is no evidence on the relationship between volatility and the transaction cost in this derivatives market. Therefore, the purpose of this study is to investigate what impact an anticipated increase in FFA price volatility will have on transaction costs in terms of BAS. Extant literature that provides some possible answers to the previous question includes those studies on the relationship between BASs and price volatility (see, for example, Benston and Hagerman, ${ }^{22}$, Stoll, ${ }^{23}$ Copeland and Galai ${ }^{24}$ and McInish and Wood, ${ }^{13}$ among others).

This study contributes to the existing literature in a number of dimensions. First, it examines the relationship between BAS and price volatility in a derivatives market where the underlying asset is a service rather than physical or financial assets. The fact that the underlying asset is a service implies that the usual cost-of-carry relationship between spot and forward prices is not valid, and the relationship must be only through agents' expectations. This also implies that there is no arbitrage link between the spot and futures prices and no inventories are held by brokers and/or market makers. Secondly, a two-step modelling specification is employed 
in order to ensure robust inferences on the relationships between variables. In the first step, the GARCH specification is used to model the volatility of FFA prices. This specification is consistent with a return distribution which is leptokurtic (speculative prices), it also allows for a long-term memory (persistence) in the variance of the conditional return distributions. The GARCH model is known to be capable of mimicking observed statistical characteristics of many time-series of return on financial assets. ${ }^{25}$ The second step investigates whether the expected conditional volatility (led by one day) has a significant positive relationship with the current BAS using the generalised method of moments (GMM) approach. $^{26}$

Thirdly, volatility in the several markets of the shipping industry are subject to sudden movements which are, at best, only partially predictable. A better understanding of the movements in FFA prices, and the consequent effect on transaction costs may provide important information and insights for market agents about the timing of trades, the sentiment and the future direction of the FFA market. For example, a widening of the BAS may discourage market agents from participating and trading, as it may indicate a period of high volatility. More specifically, traders, speculators, hedgers and arbitrageurs alike are interested in extracting information from these variables to discover how their reaction to new information can be used in predicting future prices. From a policy perspective, the issue is important because of its implications for the analysis of market liquidity and its relationship with risk. For example, Demsetz ${ }^{27}$ argues that BAS can be considered a proxy for market liquidity, since a market is regarded as liquid when large transactions can be executed with a small impact on prices. In addition, agents and regulators are interested in knowing what impact changes in these variables have on market activity. Furthermore, there are special features in these contracts which do not appear in other derivatives markets, making this study more interesting. (For example, the investigation of the issue in an OTC forward market rather than a futures market, which has not been done before, primarily owing to the lack of available data.)

The remainder of this study is organised as follows. The second section presents the literature review. The third section discusses the research methodology. A description of the data and some preliminary statistics are then presented in the fourth section. The empirical results are presented in the fifth section and the final section summarises this paper.

\section{LITERATURE REVIEW}

Demsetz $^{27}$ characterises the BAS as the cost of obtaining immediacy; the right to transact without significant delay. Microstructure theory implies that BASs must cover three costs incurred by providers of immediacy: inventory carrying costs; ${ }^{24}$ asymmetric information costs $;{ }^{28}$ and order processing costs. ${ }^{27,29}$ The inventory component should be the cost to the market-maker of maintaining open positions or demanding liquidity from other market participants and is positively related to risk. According to this view, 
volatility increases price risk and thereby pushes up spreads. ${ }^{12}$ The asymmetric information costs component may be positively correlated with price volatility and competition would affect the total size of the spread inversely. ${ }^{14}$ O'Hara ${ }^{29}$ provides a comprehensive literature and guide to the most influential theoretical work in market microstructure.

Although there are differences in the theoretical arguments, all the above empirical studies conclude that BASs are positively related to price volatility (when price change was measured over short intervals, eg daily, while the relationship became insignificant for price changes measured over longer intervals, eg monthly). Of the three different types of costs, the asymmetric information cost is the most relevant in the FFA market. Order processing costs are relatively low, and shipbrokers do not sustain any inventory carrying costs as they do not hold inventories of forward contracts. The BAS must be wider to protect brokers from the costs of providing liquidity to informed traders, which can affect the brokers unfavorably. ${ }^{24}$ In this respect, the BAS may vary with both the timing of information arrival and the uncertainty of the information flow. Moreover, the BAS might be positively related to the amount of information coming to the market. ${ }^{30,31}$

If information arrives sequentially, the more informed participants will trade first and the less informed participants will trade later. Because informed traders who acquire positive (negative) information are willing to bid (ask) a higher (lower) price to buy (sell), the spread may change according to the trading behaviour of the parties who possess private information. The trader's perceived exposure to private information determines how he/she will respond to large versus small orders and to the arrival of market-generated and other publicly available information. With regard to the uncertainty of information flows, it has been argued that less informed traders seek protection from the generation and ownership of private information in the market by requiring a higher risk premium. ${ }^{30}$ This adverse selection hypothesis suggests that the level of BASs should be related to the uncertainty of the information flow in the market. As the broker attributes a positive probability to the order being generated from informed traders, the BAS widens and, therefore, may signal the arrival of new information. Saar $^{32}$ investigates the role of demand uncertainty from a different perspective, ie uncertainty about preferences and endowments of the investors' population in introducing information content to the order flow. He shows that demand uncertainty increases both the BAS and price volatility.

In the equity market, McInish and Wood ${ }^{13}$ report that New York Stock Exchange (NYSE) equity BASs widen (decrease) with underlying volatility (trading volume and trade size) over time. Wang et al., ${ }^{17}$ using direct estimates of the BAS, examine the intra-day relationship of BASs and price volatility in the S\&P500 Index futures market and control for information effects. They find that BASs and price volatility are jointly determined and positively related. In the bond market, Kalimipalli and Warga ${ }^{15}$ - 
using an autoregressive conditional duration (ACD) model, which provides input for an ordered probit model for observed BAS find a significant positive (negative) relationship between latent volatility (trading volume proxy) and observed BAS. When repeating the exercise using a $\mathrm{GARCH}$ specification instead of the ACD model, they report that their findings are robust to alternative specifications.

In the foreign exchange market, Fieleke ${ }^{33}$ reports a positive relationship between the rate of change in the exchange rate and the cost of transacting Overturf ${ }^{34}$ finds a positive relation between BAS and price volatility measured by its standard deviations. The latter study further suggests that the uncertainty regarding the rate of change in exchange rates tends to widen the BAS. Boothe ${ }^{35}$ finds that various measures of risk and transactions volume have an impact on BASs and, in particular, he provides evidence for a positive relationship between the level of uncertainty regarding futures prices and BASs. Bollerslev and Melvin ${ }^{12}$ report a positive relationship between latent volatility and observed BAS on the Deutschemark/dollar exchange market. Using a similar framework, Gwilym et al. ${ }^{36}$ find a positive relationship between BAS for stock index options traded on the LIFFE market and the volatility of the underlying stock market index. Ding ${ }^{10}$ investigates intra-day and daily determinants of BASs in the foreign exchange futures market and argues that the number of transactions is negatively related to the BAS, whereas volatility in general is positively related to it.
Another strand of research on the relationship between BAS and price volatility concentrates on the trading hours of derivatives markets. For example, Amihud and Mendelson ${ }^{37}$ demonstrate the existence of a positive relationship at the closing hour of the NYSE, while Brock and Kleidon ${ }^{38}$ show that periodic market closure causes greater transaction demand at the open and close of trading. This greater transaction demand at open and close increases asks and lowers bids (widens the spread) - so that the spreads follow a U-shaped pattern throughout the day and also increases trading activity (volume). Subrahmanyam $^{39}$ and Foster and Viswanathan $^{40}$ also predict higher BASs at open and close because the presence of informed traders increases the adverse information component of the spread.

\section{RESEARCH METHODOLOGY}

Most of the previous empirical studies have concentrated on explaining the determinants of BASs utilising two classes of factors. The first class includes:

(1) activity variables such as volume and order size;

(2) various measures of risk;

(3) competition in market-making, such as the numbers of brokers trading in the asset;

(4) the number of transactions; and

(5) institutional ownership.

The second class of factors is related to the features of exchanges and the financial characteristics of assets. Extensive literature 
reviews are provided by Benston and Hagerman, ${ }^{22}$ Hasbrouck, ${ }^{31}$ Stoll ${ }^{41}$ and McInish and Wood, ${ }^{13}$ among others.

The measurement of price volatility is a difficult task, and many different measurement procedures have been employed in the literature. These can be subdivided into those which have used historical volatility and those which have used a forecast of the volatility. The latter are those which use the implied volatilities derived through option prices. The definition of historical price volatility employed in any particular study depends on the frequency of the available observations (ie transactions data, closing prices) and the length of period for which the volatilities are to be computed (ie days or months). It is often taken as the variance of the logarithm of the daily price relatives. This has the advantage that, as the level of the prices alters over time, the variance of the logarithm of the price relatives is more likely to be stationary than is the variance of alternative volatility measures. ${ }^{42}$

A shortcoming of the earlier studies is the way price volatility is computed. Board and Sutcliffe ${ }^{42}$ have shown that studies based on the historical estimate of volatility are sensitive to the measures of volatility used. Recent studies, however, indicate that most of the financial price series exhibit non-linear price dependencies. For example, it is possible for FFA prices to be linearly unrelated and yet be non-linearly dependent. The general evidence suggests that dependencies work through the conditional variance (and other even-ordered moments), rather than being a result of certain mis-specified first order dynamics. ${ }^{43}$ Engle's ARCH model ${ }^{44}$ and Bollerslev's GARCH model ${ }^{45}$ can capture such time variation in return distributions. There is a great deal of evidence in various financial markets that the conditional variance from the ARCH class of models provides a superior estimate of price variability (see Bollerslev et al. ${ }^{46}$ for a review). ARCH processes allow the examination of the structure and the characteristics of volatility, explicitly address the issue of time dependence in the variance and, therefore, overcome problems associated with heteroscedasticity in the data. In order to derive an estimate of the FFA volatility, the following AR-GARCH $(1,1)$ model is employed:

$$
\begin{aligned}
& \Delta F_{t}=\varphi_{0}+\sum_{i=1}^{p-1} \varphi_{i} \Delta F_{t-i}+\varepsilon_{t} ; \varepsilon_{t} \sim \operatorname{iid}\left(0, h_{t}\right) \\
& h_{t}=a_{0}+a_{1} h_{t-1}+\beta_{1} \varepsilon_{t-1}^{2}
\end{aligned}
$$

where $F_{t}$ is the natural logarithm of the daily FFA price change (average mid-point of the bid-ask quotes); $\Delta$ is the first-difference operator; and $\varepsilon_{t}$ are the residuals that follow a normal distribution with mean zero and time-varying variance $h_{t}$. Bollerslev ${ }^{25}$ shows that $\operatorname{GARCH}(1,1)$ adequately fits many economic time-series. Models are also estimated using the percentage BAS - defined as (Ask-Bid)/[(Ask+Bid)/2]. The results are qualitatively unaffected, however, and thus in the ensuing analysis the models using the differenced BAS are reported. After ensuring that the model is well specified, following Bessembinder ${ }^{14}$ and Galati, ${ }^{47}$ one-step ahead conditional volatility estimates $\left(h_{t+1}\right)$ can be constructed. 
Following a common practice in the literature, the GARCH model is fitted on the entire time-series, thus yielding in-sample forecasts. Ideally, volatility implied in FFA option prices could be used, since there is evidence in other markets that it outperforms GARCH models in providing forecasts of future volatility. ${ }^{48}$ FFA option contracts, however, are currently not very liquid.

To analyse the relationship between expected volatility and current BAS, the BASs are regressed against variables that represent risk, information, a dummy variable that serves to measure non-trading intervals, and a lagged BAS. To evaluate the importance of the approach of non-trading intervals in determining BASs, following Bessembinder, a non-trading indicator variable is included, which is set equal to one on Fridays and on the last trading day before a bank holiday in the UK. ${ }^{14}$ The results, however, yield insignificant coefficients of the dummy variable in all routes and are therefore excluded from the ensuing analysis:

$$
\begin{aligned}
\mathrm{BAS}_{t}= & \beta_{0}+\beta_{1} h_{t+1}+\beta_{2} \mathrm{BAS}_{t-1} \\
& +\beta_{3} \Delta F_{t}+u_{t} ; u_{t} \sim \operatorname{iid}\left(0, h_{t}\right)
\end{aligned}
$$

where risk is defined as the one-step ahead conditional volatility $\left(h_{t+1}\right)$ from a GARCH(1,1) model, information effects are evaluated by the first-difference FFA price series $\left(\Delta F_{t}\right)$ and $\mathrm{BAS}_{t}$ is the difference of the natural logarithm of the ask quote minus the natural logarithm of the bid quote $\left(\ln \left(\mathrm{Ask}_{t}\right)-\ln \left(\mathrm{Bid}_{t}\right)\right)$. Ding ${ }^{10}$ proposes an alternative method for evaluating information effects using a price dummy variable, calculated as follows. First, the median transaction price is identified from the entire time-series. The FFA price of each day is then compared with the overall median price. If the FFA price is greater than the median price, the dummy variable is assigned a value of one. Otherwise, a value of zero is assigned. Ding, ${ }^{10}$ however, points out that the first-difference price series, rather than the price dummy, may generally provide more information. Thus, only the results containing the first-difference price series are reported here.

Two main problems occur when examining the relationship between volatility and BAS. First, it is readily seen that the use of BAS will result in simultaneity bias leading to inconsistent ordinary least squares (OLS) estimates. In order to overcome the simultaneity problem, Harvey ${ }^{49}$ points out that lagged values of the endogenous variables should be used, because they are classified together with exogenous variables - as predetermined. The second difficulty concerns the presence of heteroscedasticity implying inefficient standard errors. Thus, the model should be estimated using the GMM approach proposed by Hansen. ${ }^{26}$ The GMM approach allows an instrument to be used for $\mathrm{BAS},{ }^{50}$ thereby avoiding any simultaneity bias when lagged BASs are used as instruments. The GMM also has the additional advantage of yielding heteroscedasticity and autocorrelation consistent estimates (as proposed by Newey and $\mathrm{West}^{51}$ ) in the process.

The use of the first-difference FFA price series in the model assists in examining the 
relationship between informational uncertainty and BASs. If high price levels result from informed trading, the relationship between price levels and BASs should be positive, as it is reported in most empirical studies. ${ }^{23,24}$ In general, large broker spreads are attributed to the risk of adverse selection or uniform trading, while a negative relationship is argued to be the result of the presence of scale economies in the market. The latter is because, when prices are high, the dollar volume of transactions is large, which means brokers require lower BAS to cover their costs. ${ }^{13}$

\section{DESCRIPTION AND PROPERTIES OF DATA}

From the creation of the FFA market on 1st February, 1992, to 1st November, 1999, the 11 Panamax and Capesize voyage and time-charter routes of the Baltic Freight Index (BFI) served as the underlying assets of the FFA trades in the dry-bulk sector of the shipping industry. After the latter date, with the exclusion of the Capesize routes and with the index renamed as BPI, the underlying assets of the FFA contracts are Panamax routes. The composition of the BPI, as it stood in January 2001, is presented in Table 1. The data sets that are used consist of daily FFA and BAS prices in Panamax Atlantic routes 1 and 1A from 16th January, 1997 to 31st July, 2000 and daily FFA and BAS prices in Panamax Pacific routes 2 and 2A from 16th January, 1997 to 10th August, 2001. All price data are from Clarkson Securities Limited. The FFA price series are transformed into natural logarithms. The FFA prices are always those of the nearby contract. To avoid thin markets and expiration effects, however, there is a rollover to the next nearest contract one week before the nearby contract expires, as there is sufficient liquidity in the nearby contract up to a few days before its maturity date.

Summary statistics for the daily logarithmic first-difference FFA prices and of the BAS prices for the four Panamax routes are presented in Table 2 . Jarque-Bera $^{52}$ tests indicate departures from normality for FFA and BAS prices in all routes. The Ljung-Box ${ }^{53} \mathrm{Q}(24)$ and $\mathrm{Q}^{2}(24)$ statistics on the first 24 lags of the sample autocorrelation function of the raw series and of the squared series indicate significant serial correlation and the existence of heteroscedasticity, respectively. After the Augmented Dickey-Fuller ${ }^{54}$ (ADF) and Phillips-Perron ${ }^{55}$ (PP) unit root tests are applied on the daily log first-difference FFA price series, the results indicate that in all routes the $\log$ first-difference FFA price series are stationary. The results of the unit root tests on the levels of the BAS series indicate that all BAS price series are stationary.

The BASs for routes 1, 1A, 2 and 2A, respectively are presented in Figures $2-5$, providing a visual representation of the transactions costs induced by the shipbrokers. The figures show that the maximum BAS for is $\$ 0.25$ per tonne for route $1, \$ 0.35$ per day for route $1 \mathrm{~A}, \$ 0.09$ per tonne for route 2 , and $\$ 0.29$ per day for route $2 \mathrm{~A}$.

Moreover, after about September 1999, the BASs for routes 2 and 2A start to narrow significantly. This, and the small BAS figures in route 2 , can be explained by the fact that 
Table 1: Baltic Panamax Index (BPI) - route definitions

\begin{tabular}{|c|c|c|c|c|}
\hline Routes & Route description & Cargo & $\begin{array}{l}\text { Vessel size } \\
(d w t)\end{array}$ & $\begin{array}{l}\text { Weightings in } \\
\text { bpi }\end{array}$ \\
\hline 1 & $\begin{array}{l}\text { 1-2 safe berths/anchorages US Gulf (Mississippi } \\
\text { River not above Baton Rouge) to ARA } \\
\text { (Antwerp, Rotterdam, Amsterdam). }\end{array}$ & Light grain & 55,000 & $10 \%$ \\
\hline $1 \mathrm{~A}$ & $\begin{array}{l}\text { Transatlantic (including ECSA) round of } 45-60 \text { days } \\
\text { on the basis of delivery and redelivery Skaw } \\
\text { Passero range. }\end{array}$ & $\mathrm{T} / \mathrm{C}$ & 70,000 & $20 \%$ \\
\hline 2 & $\begin{array}{l}\text { 1-2 safe berths/anchorages US Gulf (Mississippi River } \\
\text { not above Baton Rouge) } / 1 \text { no combo port to } \\
\text { South Japan. }\end{array}$ & HSS & 54,000 & $12.5 \%$ \\
\hline $2 \mathrm{~A}$ & $\begin{array}{l}\text { Basis delivery Skaw Passero range, for a trip via Gulf } \\
\text { to the Far East, redelivery Taiwan-Japan range, } \\
\text { duration 50-60 days. }\end{array}$ & $\mathrm{T} / \mathrm{C}$ & 70,000 & $12.5 \%$ \\
\hline 3 & $\begin{array}{l}1 \text { port US North Pacific/1 no combo port to } \\
\text { South Japan. }\end{array}$ & HSS & 54,000 & $10 \%$ \\
\hline $3 \mathrm{~A}$ & $\begin{array}{l}\text { Transpacific round of } 35-50 \text { days either via Australia } \\
\text { or Pacific (but not including short rounds such as } \\
\text { Vostochy/Japan), delivery and redelivery } \\
\text { Japan/South Korea range. }\end{array}$ & $\mathrm{T} / \mathrm{C}$ & 70,000 & $20 \%$ \\
\hline 4 & $\begin{array}{l}\text { Delivery Japan/South Korea range for a trip via } \\
\text { US West Coast - British Columbia range, } \\
\text { redelivery Skaw range, duration 50-60 days. }\end{array}$ & $\mathrm{T} / \mathrm{C}$ & 70,000 & $15 \%$ \\
\hline
\end{tabular}

Each shipping route is given an individual weighting to reflect its importance in the worldwide freight market.

Routes 1A, 2A, and 3A refer to time-charter (T/C) contracts, while 1, 2, 3, and 4 refer to voyage contracts. The vessel size is measured by its carrying capacity (dwt - deadweight tonnes) and includes the effective cargo, bunkers, lubricants, water, food rations, crew and any passengers.

HSS, heavy grain, soya and sorghum.

Source: Baltic Exchange.

routes 2 and $2 \mathrm{~A}$ concentrate most of the FFA trading interest in the Panamax sector. Thus, shipbrokers can report narrow BASs as shipowners and charterers agree to fix FFA contracts after a few negotiations only. Figures 6-9 show the historical volatility (standard deviation) of daily percentage FFA price changes, computed over moving windows of 20 days, and the BASs for routes 1, 1A, 2 and 2A, respectively. The figures show a positive relationship between volatility and BAS in most cases, which is clearer and more consistent in routes 2 and 2A. Formal empirical analysis is needed, however, for the significance of the above inference. 
Table 2: Descriptive statistics of logarithmic first difference FFA and BAS prices $\left(\ln \left(A s k_{t}\right)-\ln \left(\right.\right.$ Bid $\left.\left._{t}\right)\right)$

$$
N \quad S D \quad \text { Skew } \quad \text { Kurt } \quad Q(24) \quad Q^{2}(24) \quad J-B \quad A D F(\text { lags }) \quad P P(6)
$$

Panel A: Route 1 FFA and BAS price series (16th January, 1997 to 31st July, 2000)

$\begin{array}{lllllccccr}\text { FFA } & 896 & 0.0239 & -0.151 & 5.429 & 44.466 & 34.183 & 1,096.7 & -31.722(0) & -32.070 \\ \text { BAS } & 897 & 0.0441 & 1.103 & 4.327 & 3,236.0 & 2,698.3 & 247.548 & -8.773(0) & -8.517\end{array}$

Panel B: Route 1A FFA and BAS price series (16th January, 1997 to 31st July, 2000)

$\begin{array}{lllllccccc}\text { FFA } & 896 & 0.0301 & -0.037 & 4.708 & 35.083 & 50.891 & 822.28 & -29.547(0) & -29.936 \\ \text { BAS } & 897 & 0.0606 & 0.828 & 3.813 & 5,689.8 & 5,506.7 & 127.294 & -5.516(2) & -6.792\end{array}$

Panel C: Route 2 FFA and BAS price series (16th January, 1997 to 10th August, 2001)

$\begin{array}{lllllccccc}\text { FFA } & 1,150 & 0.0178 & 0.285 & 12.711 & 45.426 & 56.827 & 4,534.59 & -31.632(0) & -31.727 \\ \text { BAS } & 1,151 & 0.0105 & 1.369 & 6.208 & 2,452.3 & 1,420.4 & 852.907 & -12.979(1) & -16.837\end{array}$

Panel D: Route 2A FFA and BAS price series (16th January, 1997 to 10th August, 2001)

$\begin{array}{lllllcccrr}\text { FFA } & 1,150 & 0.0278 & 0.984 & 15.266 & 48.906 & 50.905 & 7,394.89 & -31.084(0) & -31.176 \\ \text { BAS } & 1,151 & 0.0381 & 1.534 & 6.499 & 8,170.1 & 7,666.8 & 1,038.29 & -7.113(2) & -9.628\end{array}$

All series are measured in logarithmic first differences.

$N$ is the number of observations.

$\mathrm{SD}$ is the standard deviation of the series.

Skew and Kurt are the estimated centralised third and fourth moments of the data; their asymptotic distributions under the null are $\sqrt{T} \hat{a}_{3} \sim N(0,6)$ and $\sqrt{T}\left(\hat{a}_{4}-3\right) \sim N(0,24)$, respectively.

$\mathrm{Q}(24)$ and $\mathrm{Q}^{2}(24)$ are the Ljung-Box ${ }^{53} \mathrm{Q}$ statistics on the first 24 lags of the sample autocorrelation function of the raw series and of the squared series, respectively; these tests are distributed as $\chi^{2}(24)$.

$\mathrm{J}-\mathrm{B}$ is the Jarque-Bera ${ }^{52}$ test for normality, distributed as $\chi^{2}(2)$.

ADF is the Augmented Dickey-Fuller ${ }^{54}$ test. The ADF regressions include an intercept term; the lag-length of the ADF test (in parentheses) is determined by minimising the Schwartz Bayesian Information Criterion (SBIC). ${ }^{56}$

$\mathrm{PP}$ is the Phillips and Perron ${ }^{55}$ test; the truncation lag for the test is in parentheses.

The $5 \%$ critical value for the ADF and PP test is -2.89 .

\section{EMPIRICAL RESULTS}

In order to model the volatility of the FFA prices, AR-GARCH(1,1) models are estimated. The most parsimonious specification for each model is estimated by excluding insignificant variables. The quasi-maximum likelihood estimates of the GARCH models of FFA rates for each route are presented in Table 3 . The diagnostic tests on the standardised residuals and squared standardised residuals indicate that models are well specified with no 
Figure 2: Route 1 BAS series; sample period 16th January, 1997 to 31st July, 2000

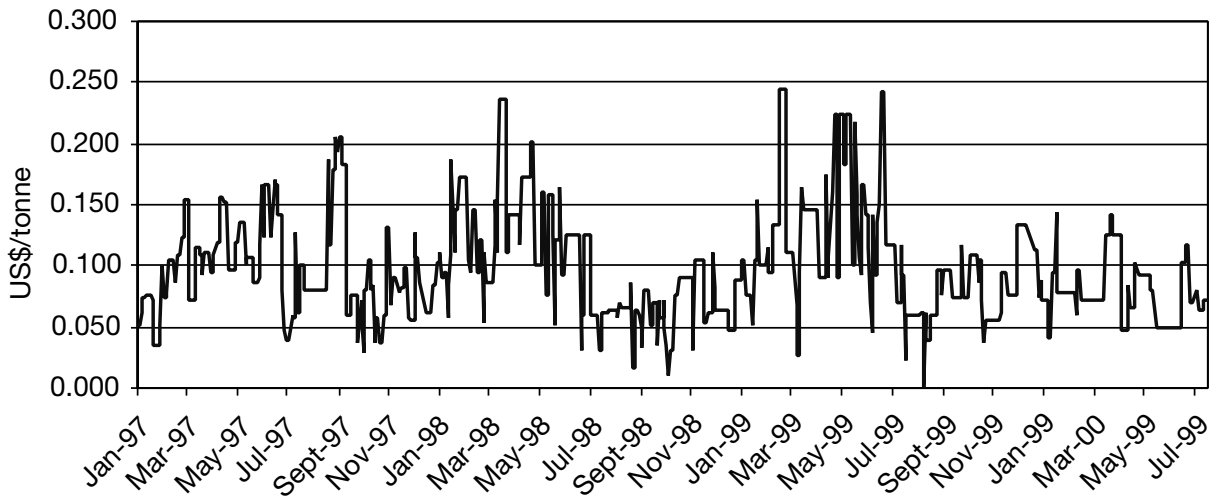

Figure 3: Route 1A BAS series; sample period 16th January, 1997 to 31st July, 2000

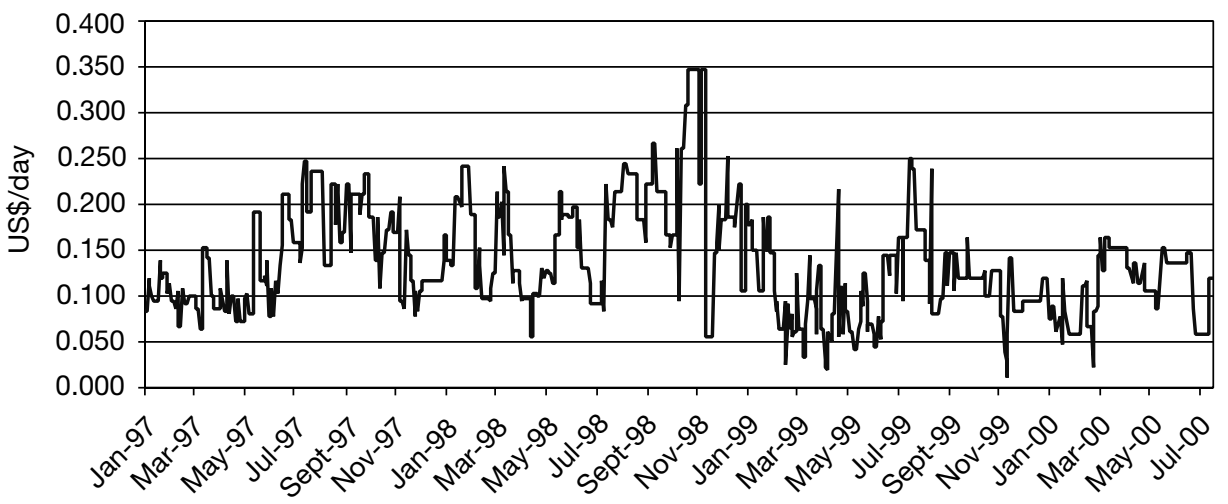

Figure 4: Route 2 BAS series; sample period 16th January, 1997 to 10th August, 2001

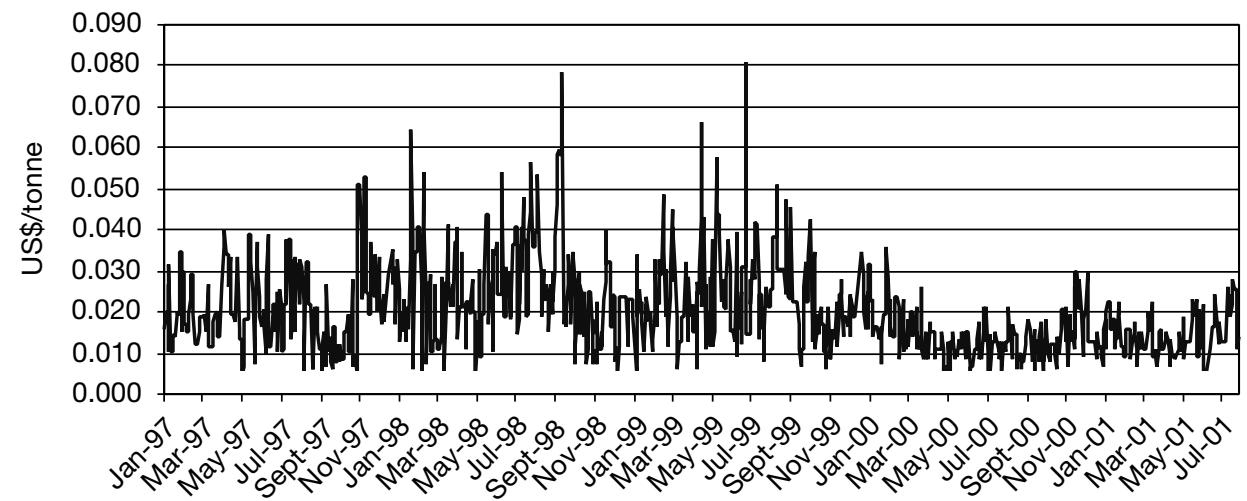


Figure 5: Route 2A BAS series; sample period 16th January, 1997 to 10th August, 2001

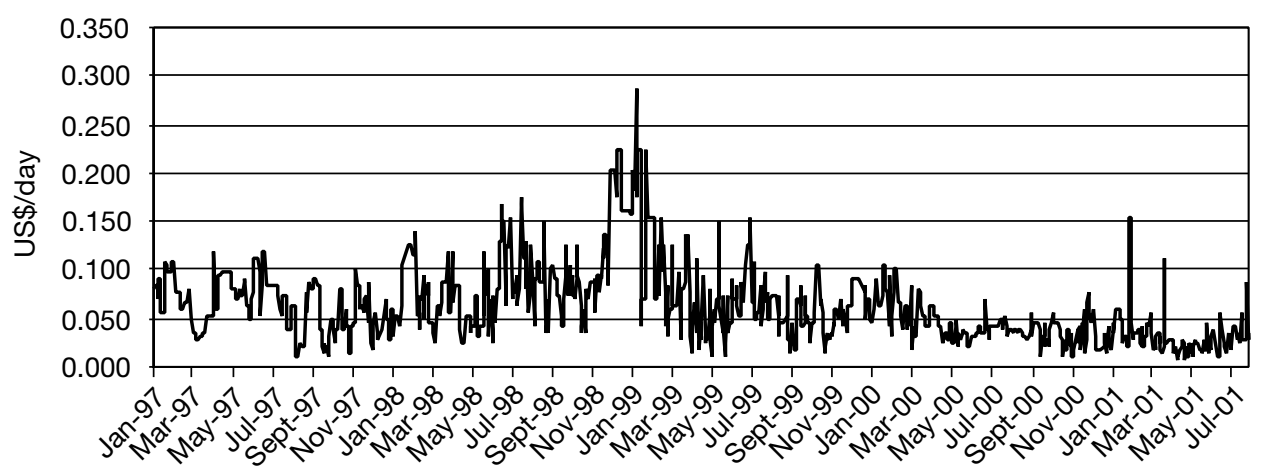

Figure 6: Route 1 BAS and historical volatility; sample period 16th January, 1997 to 4th July, 2000

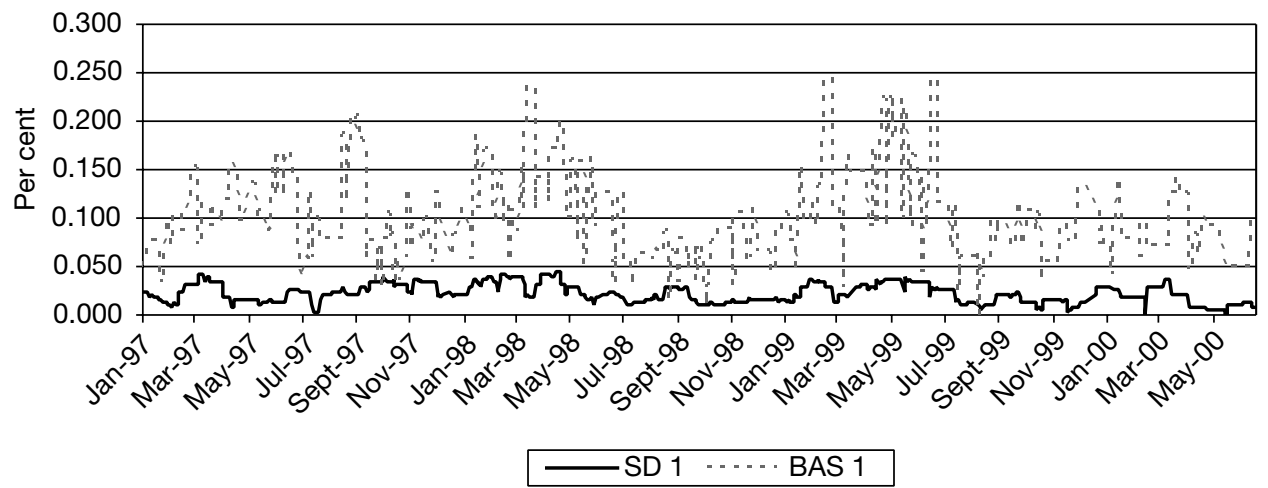

asymmetries, and there are no linear and non-linear dependencies, respectively. The estimated implied kurtosis indicates the presence of excess kurtosis in the standardised residuals in all investigated routes. As a result, the Jarque-Bera ${ }^{52}$ test rejects normality in all routes. In routes 1 and $1 \mathrm{~A}$, the coefficients of the lagged variance $\left(a_{1}\right)$ are significant, suggesting that there is a persistence effect in price volatility, while the coefficients of the lagged error-terms $\left(\beta_{1}\right)$ are insignificant. In routes 2 and $2 \mathrm{~A}$, the coefficients of the lagged variance and the lagged error terms are significant at conventional significance levels. The persistence estimates of the conditional volatility reveal the presence of a near-integrated GARCH (IGARCH) process in all trading routes, with persistence estimates close to, but slightly less than, unity. ${ }^{25}$

After estimating the GARCH(1,1) models and ensuring that they are well-specified, one step ahead conditional volatility estimates $\left(h_{t+1}\right)$ are extracted for each trading route. The results of $\mathrm{ADF}$ and $\mathrm{PP}$ unit root tests on the daily one step ahead conditional volatility estimates indicate that the 
Figure 7: Route 1A BAS and historical volatility; sample period 16th January, 1997 to 4 th July, 2000

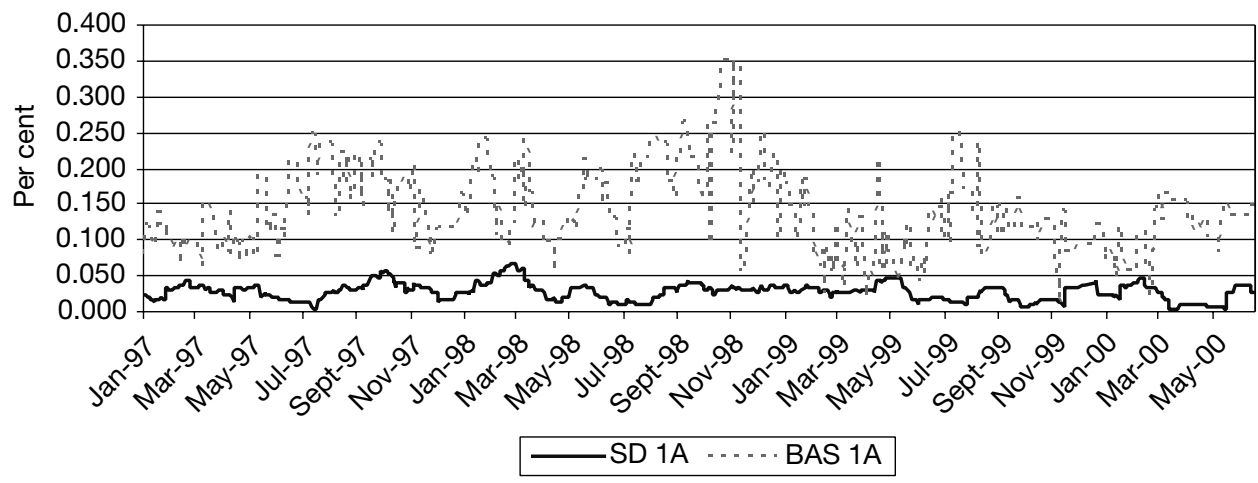

Figure 8: Route 2 BAS and historical volatility; sample period 16th January, 1997 to 16 th July, 2001

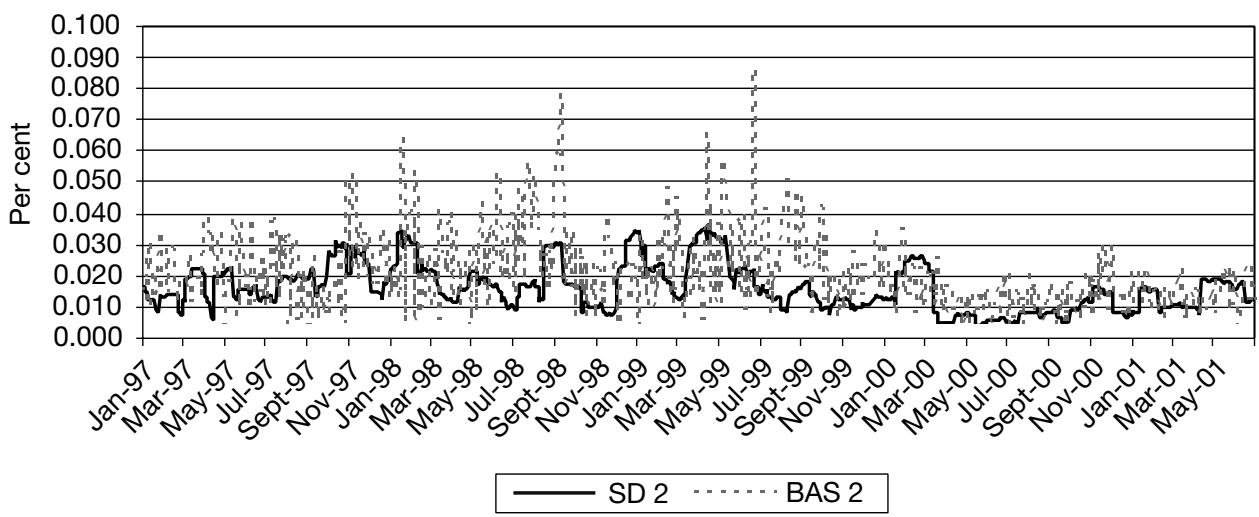

Figure 9: Route 2A BAS and historical volatility; sample period 16th January, 1997 to 16 th July, 2001

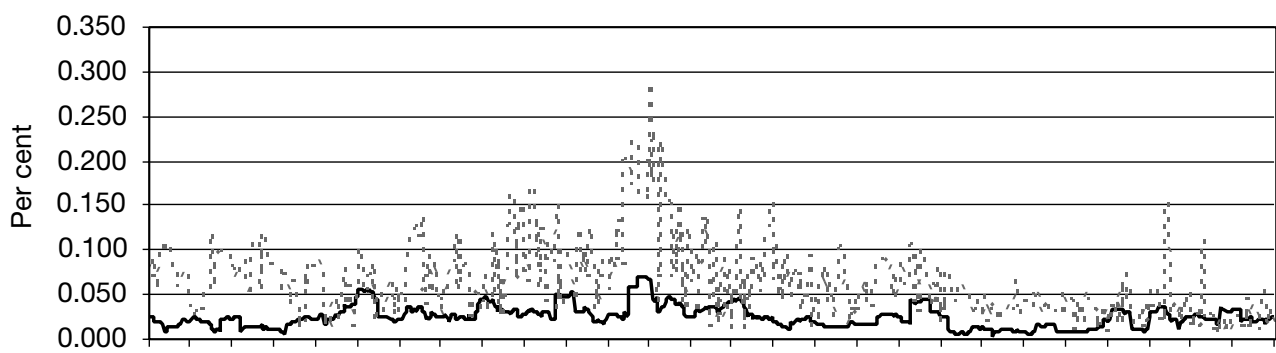

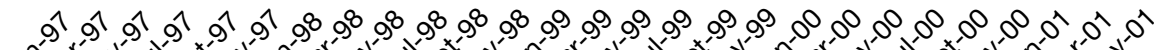

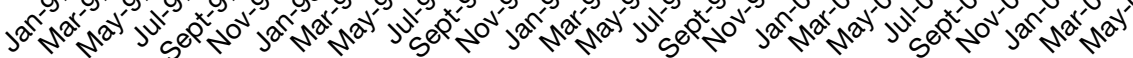

$\longrightarrow$ SD 2A $\cdots \cdots$ BAS 2A 
conditional volatility series are stationary for all routes (not reported). The BASs are then regressed against one step ahead conditional volatilities, current first-difference FFA returns and lagged BAS, to investigate the relationship between BAS and expected volatility. The results from the GMM regressions are presented in Table 4, panel A. The diagnostic tests indicate the existence of serial correlation and heteroscedasticity in most cases, and thus justify the use of the GMM approach. The adjusted $R$-squares of 0.711 for route $1,0.782$ for route $1 \mathrm{~A}, 0.407$ for route 2 and 0.683 for route $2 \mathrm{~A}$ show that 71.1 per cent, 78.2 per cent, 40.7 per cent and 68.3 per cent, respectively, of the variation in daily BASs are explained by the independent variables.

Consistent with the findings in the literature, the coefficient on the GARCH variance forecast $\left(\beta_{1}\right)$ is positive and statistically significant in routes 1,2 and $2 \mathrm{~A}$, suggesting that expected volatility has predictive power in determining BASs through its effect on asymmetric information costs. This result was expected, as anticipated large price changes may be correlated with the presence of information traders, and FFA brokers might increase the BAS to compensate for expected losses when trading with informed traders. In terms of magnitude, the elasticity of BASs with respect to price volatility is higher in route 1 (20.409) than those in routes 2 (13.517) and 2A (5.839). These results are in accordance with Figures 1-4, which indicate that in routes 2 and 2A the BASs are significantly narrower than in route 1 , as routes 2 and $2 \mathrm{~A}$ concentrate most of the FFA trading interest in the Panamax sector. The finding of the $\beta_{1}$ coefficient being negative and insignificant in route $1 \mathrm{~A}$ is in stark contrast to the findings in the literature, and is possibly explained by the infrequent FFA trading activity.

The coefficients of lagged BASs $\left(\beta_{2}\right)$ are positive and significant at the 1 per cent level. This suggests that the dynamic adjustment of the BAS is not usually completed in a one day period for the selected forward contracts. The coefficient of the first-difference FFA price series $\left(\beta_{3}\right)$ is found to be negatively significant in route 2 only. In the other three routes investigated, the $\beta_{3}$ coefficient is insignificant. This finding, in route 2 , dominates the presence of any asymmetric information trading. It is, therefore, consistent with the presence of trading economies in the FFA market of route 2 . It also supports the results of McInish and Wood $^{13}$ for the stock market and of Ding ${ }^{10}$ for the currency futures market. Copeland and Galai ${ }^{24}$ argue that higher price levels in the stock market are associated with larger spreads because of a higher informational uncertainty due to bidding up of prices by informed traders. By contrast, the findings of lower spread levels when prices increase support the notion of the presence of economies of scale (when prices are high, the dollar volume of transactions rises, leading to a lowering of brokers' required BAS to cover their costs) in trading FFA contracts in route 2 .

In order to verify the previous inferences, the relationship between BASs and volatility is further estimated where, as a measure of historical volatility, the one step ahead variances of daily percentage FFA price changes are used, computed over moving 
Table 3: GARCH model estimates of the FFA conditional volatility

$$
\begin{array}{r}
\Delta F_{t}=\varphi_{0} \sum_{i=1}^{p-1} \varphi_{i} \Delta F_{t-i}+\varepsilon_{t} ; \varepsilon_{t} \sim \operatorname{iid}\left(0, h_{t}\right) \\
h_{i}=a_{0}+a_{1} h_{t-1}+\beta_{1} \varepsilon_{t-1}^{2} \quad(1 \mathrm{~b}) \\
\text { Route 1 } \\
\text { (16th January, 1997- } \\
\text { 31st July, 2000) }
\end{array}
$$

Route $1 A$

(16th January, 1997-

31st July, 2000)
Route 2

(16th January, 1997-

10th August, 2001)
Route $2 A$

(16th January, 1997-

10th August, 2001)

$$
\begin{gathered}
-0.0002(-0.425) \\
0.065 \star(2.339) \\
1.7 \mathrm{E}-06(0.964) \\
0.981 \star(93.471) \\
0.013 \star \star(1.997)
\end{gathered}
$$$$
0.925 \star(12.391)
$$$$
0.018(1.139)
$$

$0.969 \star(28.715)$

$0.011(1.362)$

Panel B: Residual diagnostic

LL

Skewness

$2,079.5$

Kurtosis

$\mathrm{J}-\mathrm{B}$

$\mathrm{Q}(12)$

$\mathrm{Q}^{2}(12)$

0.004

13.260

$3,925.8$

15.550 [0.159]

$5.046[0.929]$

$\mathrm{ARCH}(5)$

$\mathrm{ARCH}(12)$

Persistence

0.259 [0.935]

0.386 [0.969]

UV

$$
0.980
$$

0.000425

Sign bias

$-0.545[0.586]$

Negative size bias

Positive size bias

0.627 [0.531]

0.270 [0.787]

Joint test for

0.161 [0.922]
$1,876.7$

0.304

11.275

$2,570.4$

10.056 [0.611]

$12.945[0.373]$

0.408 [0.843]

1.096 [0.359]

0.943

0.000772

-1.115 [0.265]

$0.562[0.575]$

$-0.086[0.932]$

0.496 [0.685]
3,032.7

0.422

13.704

5,519.8 [0.000]

15.288 [0.170]

4.165 [0.965]

0.242 [0.944]

0.339 [0.982]

0.994

0.000283

-0.924 [0.356]

0.352 [0.725]

$-0.565[0.572]$

0.623 [0.601]
$-0.0004(0.512)$

$0.099 \star(3.638)$

$7.1 \mathrm{E}-06(1.142)$

$0.970 \star(67.859)$

$0.021 \star(2.459)$

three effects

Figures in parentheses (.) and in squared brackets [.] indicate $t$-statistics and exact significance levels, respectively. $\star$ and $\star \star$ indicate significance at the $5 \%$ and $10 \%$ levels, respectively.

The GARCH process is estimated with the QMLE. The BHHH algorithm maximised the QMLE.

LL is the Log-Likelihood. J-B is the Jarque-Bera ${ }^{52}$ normality test. $\mathrm{Q}(12)$ and $\mathrm{Q}^{2}(12)$ are the Ljung-Box ${ }^{53}$ tests for 12th order serial correlation and heteroscedasticity in the standardised residuals and in the standardised squared residuals, respectively. $\mathrm{ARCH}($.$) is the Engle's { }^{44} F$-test for autoregressive conditional heteroscedasticity.

Persistence is defined as the degree of convergence of the conditional volatility to the unconditional volatility after a shock and is calculated as $a_{1}+\beta_{1}$.

UV is the unconditional volatility estimate of the GARCH models, measured as $\left(a_{0}\right) /\left(1-a_{1}-\beta_{1}\right)$.

The test statistics for the Engle and $\mathrm{Ng}^{57}$ tests are the $t$-ratio of $b$ in the regressions: $e \sigma_{t}^{2}=a_{0}+a_{1} Y_{t-1}^{-}+\omega_{t}$ (sign bias test); $e \sigma_{t}^{2}=a_{0}+a_{1} Y_{t-1}^{-} \varepsilon_{t-1}+\omega_{t}$ (negative size bias test); $e \sigma_{t}^{2}=a_{0}+a_{1} Y_{t-1}^{+} \varepsilon_{t-1}+\omega_{t}$ (positive size bias test), where $e \sigma_{t}^{2}$ are the squared standardised residuals $\varepsilon_{t}^{2} / \sigma_{t}$. $Y_{t-1}^{-}$is a dummy variable taking the value of one when $\varepsilon_{t-1}$ is negative and zero otherwise, and $Y_{t-1}^{+}=1-Y_{t-1}^{-}$. The joint test is based on the regression $e \sigma_{t}^{2}=a_{0}+a_{1} Y_{t-1}^{-}+a_{2} Y_{t-1}^{-} \varepsilon_{t-1}+a_{3} Y_{t-1}^{+} \varepsilon_{t-1}+\omega_{t}$. The joint test $\mathrm{H}_{0}: a_{1}=a_{2}=a_{3}=0$, is an $F$ test with $95 \% \mathrm{critical}$ value of 2.60.

FFA, Forward Freight Agreement 
Table 4: GMM estimates of the relationship between BAS and price volatility

$\mathrm{BAS}_{t}=\beta_{0}+\beta_{1} h_{t-1}+\beta_{2} \mathrm{BAS}_{t-1}+\beta_{3} \Delta F_{t}+u_{t} ; u_{t} \sim \operatorname{iid}\left(0, h_{t}\right)$

$\begin{array}{llll}\text { Route } 1 & \text { Route } 1 A & \text { Route } 2 & \text { Route } 2 A\end{array}$

$\begin{array}{lllll}\text { Explanatory } & \text { (16th January, 1997- } & \text { (16th January, 1997- } & \text { (16th January, 1997- } & \text { (16th January, 1997- } \\ \text { variables } & \text { 30th July, 2000) } & \text { 30th July, 2000) } & \text { 9th August, 2001) } & \text { 9th August, 2001) }\end{array}$

Panel A: Volatility measured as the conditional variance of GARCH models

$\begin{array}{lcccl}\beta_{0} & 0.005(1.095) & 0.019 \star(3.295) & 0.004^{\star}(6.313) & 0.008^{\star}(4.452) \\ \beta_{1} & 20.409^{\star}(2.176) & -3.524(0.657) & 13.517 \star(4.948) & 5.839^{\star}(3.175) \\ \beta_{2} & 0.827 \star(31.421) & 0.884^{\star}(37.958) & 0.573^{\star}(12.002) & 0.801^{\star}(27.456) \\ \beta_{3} & -0.098(-1.191) & 0.0256(0.333) & -0.052^{\star}(-2.081) & 0.068(1.317)\end{array}$

Diagnostics

$\begin{array}{lllll}R^{2} & 0.711 & 0.782 & 0.407 & 0.683\end{array}$

$\begin{array}{lllcr}\mathrm{Q}(12) & 19.048[0.087] & 30.793[0.002] & 45.401[0.000] & 54.154[0.000] \\ \mathrm{Q}^{2}(12) & 64.458[0.000] & 28.599[0.005] & 185.82[0.000] & 140.69[0.000]\end{array}$

Panel B: Volatility measured as the rolling variances

$\begin{array}{lcccc}\beta_{0} & 0.014 \star(6.611) & 0.017 \star(5.235) & 0.007 \star(8.929) & 0.010 \star(7.639) \\ \beta_{1} & 5.242^{\star}(2.640) & -0.120(-0.121) & 2.978^{\star}(2.773) & 4.530 \star(5.039) \\ \beta_{2} & 0.826^{\star}(29.962) & 0.883^{\star}(36.913) & 0.599 \star(15.206) & 0.783 \star(29.699) \\ \beta_{3} & -0.099(-1.220) & 0.036(0.472) & 0.040 \star(1.993) & 0.065(1.252) \\ \text { Diagnostics } & & & 0.392 & 0.687 \\ R^{2} & 0.710 & 0.779 & 59.030[0.000] & 54.781[0.000] \\ Q(12) & 18.348[0.106] & 31.310[0.002] & 150.01[0.000] & 134.39[0.000] \\ Q^{2}(12) & 57.074[0.000] & 27.520[0.006] & \end{array}$

Figures in parentheses (.) and in squared brackets [.] indicate $t$-statistics and exact significance levels, respectively.

$\star$ and $\star \star$ denote significance at the $5 \%$ and $10 \%$ levels, respectively.

Volatility, in panel A, is defined as the one-step ahead conditional variance of the FFA prices, computed from a well-specified GARCH(1,1) model.

Volatility, in panel B, is defined as the one-step ahead variance of percentage FFA price changes, computed over moving-windows of 20 days.

$\mathrm{Q}(12)$ and $\mathrm{Q}^{2}(12)$ are the Ljung-Box ${ }^{53}$ tests for 12th order serial correlation and heteroscedasticity in the residuals and in the squared residuals, respectively.

$R^{2}$ is the adjusted $R$-squared of the regression.

The GMM method uses a weighting matrix $\left(A=\hat{\Omega}^{-1}\right)$ that is robust to heteroscedasticity and autocorrelation of unknown form. The covariance matrix $(\hat{\Omega})$ is defined as: $\hat{\Omega}=\hat{\Gamma}(0)+\left(\sum_{j=1}^{T=1} k(j, q)\left[\hat{\Gamma}(j)-\hat{\Gamma}^{\prime}(j)\right]\right)$, where $\hat{\Gamma}(j)=1 / T-k\left(\sum_{i=j+1}^{T} Z^{\prime} i-j U i U^{\prime} i-j Z i\right)$, the kernel $(k)$ is set to Bartlett functional form, and the truncation lag window $(q)$ is set to Newey-West fixed bandwidth selection criterion.

BAS, bid-ask spread; FFA, Forward Freight Agreement; GMM, general method of moment 
windows of 20 days (approximately one trading month). The results, presented in Table 4, panel B, are in accordance with previous results, as the coefficients of the statistically constructed measure of volatility $\left(\beta_{1}\right)$ are positive and statistically significant in routes 2 and $2 \mathrm{~A}$. In route $1 \mathrm{~A}$, as expected, the $\beta_{1}$ coefficient is negative and insignificant. The coefficients of lagged BASs $\left(\beta_{2}\right)$ are positively significant at the 1 per cent level and the coefficients of the first-difference FFA price series $\left(\beta_{3}\right)$ are found to be negatively significant in route 2 only.

\section{CONCLUSION}

The microstructure of the freight forward market differs in several ways from that of the often examined derivatives markets, providing an interesting alternate market for developing and testing microstructure theories. This paper utilises a two-step model that attempts to explain some of the empirical regularities cited in the microstructure literature. The study contributes to the general literature by examining an OTC forward market, extending the concepts associated with forward prices to non-storable commodities (eg services), with no explicit storage relationship linking spot and forward prices. In addition, a feature of this market is higher transaction costs in spot compared with the FFA market. Some new evidence is provided on interactions between expected volatility and BASs from finding that FFA spreads vary with proxies for asymmetric information costs, including alternative risk forecasts. More specifically, results indicate that there is a positive relationship between BASs and expected price volatility in routes 1,2 and $2 \mathrm{~A}$, after other factors are controlled. By contrast, in route $1 \mathrm{~A}$ no significant relationship between BASs and expected volatility is observed This finding may be explained by the thin trading of the FFA contracts in the latter route.

The results of this study can provide a better understanding of the movements of FFA prices and the consequent effect in transactions costs. Market agents using the information on the behaviour of the BASs can gain better insight into the timing of their FFA transactions and the future direction of the FFA market, as a widening BAS corresponds to an anticipation of increased future volatility. As a policy implication, FFABA should consider how its future policy decisions may affect the volatility of the market and, consequently, the BASs. Although this study investigated and identified some key determinants of BASs in the freight forward market, it recognises the possibility that others may exist (ie trading volume). In general, however, risk is thought to be a stable determinant and is found to support those of previous studies.

\section{References and notes}

1 The credit risk associated with forward contracts can take the form of risk that occurs when one party is not performing, on the expiration date, the obligations relative to a change in the value of the forward contract from zero. If, during the life of the contract, the forward price continually mirrors the spot price, there is negligible credit risk associated with the forward contract and the contract can be sold at the market price.

2 In futures markets, the trader is required to place 
an initial margin with the clearing-house, which is an amount of money on a per contract basis and is set at a size to cover the clearing house against any losses which the trader's new position might incur during the day. Moreover, futures contracts are mark-to-market at the end of each trading day. That is, the resulting profit or loss is settled on that day. Traders are required to post a variation margin in order to cover the extent to which their trading positions show losses.

3 Bhattacharya, M. (1983) 'Transactions Data Tests of Efficiency of the Chicago Options Exchange', Journal of Financial Economics, Vol. 12, pp. 161-185.

4 Roll, R. (1984) 'A Simple Measure of the Effective Bid-Ask Spread in Efficient Market', Journal of Finance, Vol. 39, pp. 1127-1139.

5 Choi, J., Salandro, D. and Shastri, K. (1988) 'On the Estimation of Bid-Ask Spreads: Theory and Evidence', Journal of Financial and Quantitative Analysis, Vol. 23, pp. 219-230.

6 Thompson, S. R. and Waller, M. L. (1988) 'Determinants of Liquidity Costs in Commodity Futures Markets', Review of Futures Markets, Vol. 7, No. 1, pp. 111-126.

7 George, T., Gautam, K. and Nimalendran, M. (1991) 'Estimation of the Bid-Ask Spread and its Components: A New Approach', Review of Financial Studies, Vol. 4, pp. 623-656.

8 Laux, P. and Senchack, A. (1992) 'Bid-Ask in Financial Futures', Journal of Futures Markets, Vol. 12, pp. 621-634.

9 Chu, Q. C., Ding, D. K. and Pyun, C. S. (1996) 'Bid-Ask Bounce and Spreads in the Foreign Exchange Futures Market', Review of Quantitative Finance and Accounting, Vol. 6, pp. 19-37.

10 Ding, D. K. (1999) 'The Determinants of Bid-Ask Spreads in the Foreign Exchange Futures Markets: A Microstructure Analysis', Journal of Futures Markets, Vol. 19, pp. 307-324.

11 Tinic, S. M. and West, R. R. (1972) 'Competition and the Pricing of Dealer Services in the Over-the-Counter Stock Market', Journal of Financial and Quantitative Analysis, Vol. 7, pp. 1707-1728.

12 Bollerslev, T. and Melvin, M. (1994) 'Bid-Ask Spreads and Volatility in the Foreign Exchange Market: An Empirical Analysis', Journal of International Economics, Vol. 36, pp. 355-372.

13 McInish, T. and Wood, R. (1992) 'An Analysis of Intraday Patterns in Bid/Ask Spreads for NYSE Stocks', Journal of Finance, Vol. 47, pp. 753-764.

14 Bessembinder, H. (1994) 'Bid-Ask Spreads in the Interbank Foreign Exchange Markets', Journal of
Financial Economics, Vol. 35, No. 3, pp. 317-348.

15 Kalimipalli, M. and Warga, A. (2000) 'Bid/Ask Spread, Volatility and Volume in the Corporate Bond Market', (unpublished manuscript).

$16 \mathrm{Ma}, \mathrm{C} . \mathrm{K}$., Peterson, R. L. and Sears, R. S. (1992) 'Trading Noise, Adverse Selection and the Intraday Bid-Ask Spreads in Futures Markets', Journal of Futures Markets, Vol. 12, No. 5, pp. 519-538.

17 Wang, G. H. K., Michalski, R. J., Jordan, J. V. and Moriarty, E. J. (1994) 'An Intraday Analysis of Bid-Ask Spreads and Price Volatility in the S\&P500 Index Futures Market', Journal of Futures Markets, Vol. 14, No. 7, pp. 837-859.

18 Wang, G. H. K. and Yau, J. (2000) 'Trading Volume, Bid-Ask Spread, and Price Volatility in Futures Markets', Journal of Futures Markets, Vol. 20, No. 10, pp. 943-970.

19 Kavussanos, M., Visvikis, I. and Menachof, D. (2005) 'The Unbiasedness Hypothesis in the Freight Forward Marke: Evidence from Cointegration Tests', Review of Derivatives Research, Vol. 7, No. 3, pp. 241-266.

20 Kavussanos, M. and Visvikis, I. (2004) 'Market Interactions in Returns and Volatilities between Spot and Forward Shipping Markets', Journal of Banking and Finance, Vol. 28, No. 8, pp. 2015-2049.

21 Batchelor, R., Alizadeh, A. and Visvikis, I. (2003) 'Forecasting Performance of Spot and Forward Prices in the Freight Forward Market', Conference Proceedings, 23rd International Symposium on Forecasting, Merida-Yucatan, Mexico, 15th-18th June. Also in 13th International Association of Maritime Economists (IAME) Conference, Busan, Korea, 3rd-5th September.

22 Benston, G. and Hagerman, R. (1974) 'Determinants of Bid-Asked Spreads in the Over-the-Counter Market', Journal of Financial Economics, Vol. 35, pp. 351-364.

23 Stoll, H. R. (1978) 'The Supply of Dealer Services in Securities Markets', Journal of Finance, Vol. 23, pp. 1133-1151.

24 Copeland, T. and Galai, D. (1983) 'Information Effects on the Bid-Ask Spread', Journal of Finance, Vol. 38, pp. 1457-1469.

25 Bollerslev, T. (1987) 'A Conditional Heteroskedastic Time Series Model for Speculative Prices and Rates of Return', Review of Economics and Statistics, Vol. 69, pp. 542-547.

26 Hansen, L. P. (1982) 'Large Sample Properties of Generalised Method of Moments Estimation', Econometrica, Vol. 50, pp. 1029-1054.

27 Demsetz, H. (1968) 'The Cost of Transacting', 
Quarterly Journal of Economics, Vol. 82, No. 1, pp. 33-53.

28 Tinic, S. M. (1972) 'The Economics of Liquidity Services', Quarterly Journal of Economics, Vol. 86, No. 1, pp. 79-93.

29 O'Hara, M. (1995) 'Market Microstructure Theory', Blackwell, New York, NY.

30 Glosten, L. R. and Milgrom, P. (1985) 'Bid, Ask and Transactions Prices in a Specialist Market with Heterogeneously Informed Traders', Journal of Financial Economics, Vol. 14, pp. 71-100.

31 Hasbrouck, J. (1988) 'Trades, Quotes, Inventories and Information', Journal of Financial Economics, Vol. 22, pp. 229-252.

32 Saar, J. (2000) 'Demand Uncertainty and the Information Content of the Order Flow', Working Paper, Stern School of Business, New York University, NY.

33 Fieleke, N. (1975) 'Exchange-Rate Flexibility and the Efficiency of the Foreign-Exchange Markets', Journal of Financial and Quantitative Analysis, Vol. 10, pp. 409-428.

34 Overturf, S. (1982) 'Risk, Transactions Charges, and the Market for Foreign Exchange Services', Economic Inquiry, Vol. 20, pp. 291-302.

35 Boothe, P. (1988) 'Exchange Rate Risk and the Bid-Ask Spread: A Seven Country Comparison', Economic Inquiry, Vol. 26, pp. 485-492.

36 Gwilym, O., Clare, A. and Thomas, S. (1998)

'Price Clustering and Bid-Ask Spreads in International Bond Futures', International Financial Markets, Institutions and Money, Vol. 8, pp. 377-391.

37 Amihud, Y. and Mendelson, H. (1987) 'Trading Mechanism and Stock Return: An Empirical Investigation', Journal of Finance, Vol. 42, pp. 533-553.

38 Brock, W. A. and Kleidon, A. W. (1992) 'Periodic Market Closure and Trading Volume: A Model of Intraday Bids and Asks', Journal of Economic Dynamics and Control, Vol. 16, pp. 451-489.

39 Subrahmanyam, A. (1989) 'Risk Aversion, Market Liquidity and Price Efficiency’, Working Paper, Anderson Graduate School of Management, University of California at Los Angeles, CA.

40 Foster, F. and Viswanathan, S. (1994) 'Strategic Trading with Asymmetrically Informed Traders and Long-Lived Information', Journal of Financial and Quantitative Analysis, Vol. 29, pp. 499-518.

41 Stoll, H. R. (1989) 'Inferring the Components of the Bid-Ask Spread: Theory and Empirical Tests', Journal of Finance, Vol. 44, pp. 115-134.

42 Board, J. and Sutcliffe, C. (1990) 'Information, Volatility, Volume, and Maturity: An Investigation of Stock Index Futures', Review of Futures Markets, Vol. 9, No. 3, pp. 533-547.

43 Engle, R. F. and Rothschild, M. (1992) 'Statistical Models for Financial Volatility', Journal of Econometrics, Vol. 52, pp. 1-4.

44 Engle, R. F. (1982) 'Autoregressive Conditional Heteroskedasticity with Estimates of the Variance of United Kingdom Inflation', Econometrica, Vol. 50, No. 4, pp. 987-1008.

45 Bollerslev, T. (1986) 'Generalised Autoregressive Conditional Heteroskedasticity', Journal of Econometrics, Vol. 31, pp. 307-327.

46 Bollerslev, T., Chou, R. Y. and Kroner, K. F. (1992) 'ARCH Modelling in Finance: A Review of Theory and Empirical Evidence', Journal of Econometrics, Vol. 52, pp. 5-59.

47 Galati, G. (2000) 'Trading Volumes, Volatility and Spreads in Foreign Exchange Markets: Evidence from Emerging Market Countries', Working Paper, Bank of International Settlements, Monetary and Economic Department, Basel, Switzerland.

48 Jorion, P. (1996) 'Risk and Turnover in the Foreign Exchange Market', in Frankel, A., Galli, K. and Giovannini, L. (eds), 'The Microstructure of Foreign Exchange Markets', University of Chicago Press, Chicago, IL, pp. 19-36.

49 Harvey, A. C. (1989) 'Forecasting, Structural Time Series Models and the Kalman Filter', Cambridge University Press, Cambridge, UK.

50 In order to estimate the model, lagged values of BASs are used as an instrument for BAST.

51 Newey, W. K. and West, K. D. (1987) 'A Simple Positive Definite Heteroskedasticity and Autocorrelation Consistent Covariance Matrix', Econometrica, Vol. 55, pp. 703-708.

52 Bera, A. K. and Jarque, C. M. (1980) 'Efficient Tests for Normality, Heteroskedasticity, and Serial Independence of Regression Residuals', Economic Letters, Vol. 6, pp. 255-259.

53 Ljung, M. and Box, G. (1978) 'On a Measure of Lack of Fit in Time Series Models', Biometrica, Vol. 65, pp. 297-303.

54 Dickey, D. A. and Fuller, W. A. (1981) 'Likelihood Ratio Statistics for Autoregressive Time Series with a Unit Root', Econometrica, Vol. 49, pp. 1057-1072.

55 Phillips, P. C. B. and Perron, P. (1988) 'Testing for a Unit Root in Time Series Regressions', Biometrica, Vol. 75, pp. 335-346.

56 Schwartz, G. (1978) 'Estimating the Dimension of a Model', Annals of Statistics, Vol. 6, pp. 461-464.

57 Engle, R. F. and Ng, V. K. (1993) 'Measuring and Testing the Impact of News on Volatility', Journal of Finance, Vol. 48, No. 5, pp. 1749-1778. 